Abstracta Iranica Abstracta Iranica

Revue bibliographique pour le domaine irano-aryen

Volume 26 | 2005

Comptes rendus des publications de 2003

\title{
«Forgeries from Chinese Turkestan in the British Library's Hoernle and Stein collections ». BAI 14 (2000 [2003]), pp. 111-129, 17 figs.
}

\section{Mauro Maggi}

\section{(2) OpenEdition}

Journals

Édition électronique

URL : http://journals.openedition.org/abstractairanica/1468

ISSN : 1961-960X

Éditeur :

CNRS (UMR 7528 Mondes iraniens et indiens), Éditions de l'IFRI

Édition imprimée

Date de publication : 15 mai 2005

ISSN : 0240-8910

\section{Référence électronique}

Mauro Maggi, « «Forgeries from Chinese Turkestan in the British Library's Hoernle and Stein collections ». BAl 14 (2000 [2003]), pp. 111-129, 17 figs. », Abstracta Iranica [En ligne], Volume 26। 2005, document 18, mis en ligne le 08 décembre 2005, consulté le 25 septembre 2020. URL : http:// journals.openedition.org/abstractairanica/1468

Ce document a été généré automatiquement le 25 septembre 2020.

Tous droits réservés 


\title{
« Forgeries from Chinese Turkestan in the British Library's Hoernle and Stein collections ». BAI $14(2000$ [2003]), pp. 111-129, 17 figs.
}

\author{
Mauro Maggi
}

This is a well-documented history, also based on archive materials, of how diplomats and archaeologists acquired in Chinese Central Asia fake manuscripts produced by Islam Akhun and his accomplices in 1895-1898 and presumably by some of his former partners in the early 1930 's. S.-W. deals with the forgeries in the British Library but also provides information on fakes acquired by institutions of other countries. Islam Akhun's forgeries are imaginary imitations of manuscripts in formal Brāhmī (potentially Khotanese), Aramaic (initially thought to be Pahlavi), Uighur, Arabic, Chinese and Cyrillic. Later forgeries imitate manuscripts in Brāhmī script, both cursive (on the model of Khotanese documents) and formal, at times used interlinearly. By way of comparison, the article also reproduces the Khotanese document Or. 11344/5, previously unpublished in facsimile (fig. 13). It may be added that in Or. 13873/56 (ca. 1895, fig. 4), one of the first forgeries in pseudo-Brāhmī sold by Islam Akhun, the text is arranged in four columns in clear imitation of the main manuscript of the Khotanese Book of Zambasta. 
INDEX

Keywords : manuscript, forgeries, British Library, Central Asia

Mots-clés : manuscrit, faux

Thèmes : 1.3. Ouvrages généraux, histoire de la discipline nompropre Asie Centrale

\section{AUTEURS}

MAURO MAGGI

Istituto Universitario Orientale - Naples 